\title{
VLIV VEGETAČNÍ STŘECHY A KLASICKÉ PLOCHÉ STŘECHY NA TEPELNOU STABILITU OBJEKTU
}

\author{
THE EFFECT OF A GREEN ROOF VS. A CONVENTIONAL FLAT ROOF \\ ON THERMAL STABILITY OF A BUILDING
}

Josef Polášek ${ }^{*}, 1$, David Průša ${ }^{1}$, Stanislav Štastník ${ }^{1}$, Karel Šuhajda ${ }^{1}$

\author{
*146320@vutbr.cz \\ ${ }^{1}$ Fakulta stavební VUT v Brně, Veveři 331/95, 60200 Brno
}

\begin{abstract}
Abstrakt
Předložená práce se zabývá posouzením vlivu vegetační střechy na průběh teplot $\mathrm{v}$ jednotlivých místnostech dřevěné budovy tzv. dynamickou metodou numerického modelování, která je založena na principu nestacionární diferenční Schmidtovy metody. Jako okrajové podmínky potřebné pro výpočet byly využity klimatické údaje z meteorologické stanice na letišti Brno Tuřany.
\end{abstract}

\section{Klíčová slova}

Vegetační střecha, tepelná stabilita, vnitřní mikroklima, dřevostavba

\section{Abstract}

The presented work deals with assessing the influence of a green roof on the temperature course in individual rooms of a timber structure by the so-called dynamic numerical modelling method, which is based on the principle of non-stationary differential Schmidt method. Climatic data from the meteorological station at Brno Tuřany airport were used as boundary conditions for the calculation.

\section{Key words}

Green roof, thermal stability, indoor microclimate, timber structure

\section{1 ÚVOD}

Vegetační střecha, nebo také zelená střecha, je částečně až zcela pokrytá vegetací a půdou či pěstebním substrátem, které se pokládají nad hydroizolační vrstvu [1]. Mimo to, že se jedná o moderní architektonický prvek, spočívá hlavní výhoda takové střechy v tom, že vegetační prvky prodlužují životnost hydroizolace, kterou chrání před extrémními teplotami a klimatickými změnami, navíc dochází také k produkci kyslíku a zadržování nejen oxidu uhličitého, ale i různých škodlivých látek. Vegetace také filtruje prachové částice a zamezuje jejich víření. Nesporným pozitivem vegetačních střech je jejich hydroakumulační vlastnost, čímž napomáhají k zadržování srážkových vod. Tato konkrétní vlastnost má pozitivní vliv i na okolní prostředí a při větších plochách napomáhá v letních měsících snižovat teploty interiéru i exteriéru. Zároveň střecha slouží jako zvuková a tepelná izolace, přičemž dokáže, oproti klasické ploché střeše, lépe korigovat teplotní výkyvy letních i zimních období. Tento typ střechy má bezpochyby také své estetické a ekologické klady, stává se domovem pro mnoho druhů hmyzu, ptactvo atd. Pro majitele je i skvělým relaxačním místem uprostřed města, navíc není výjimkou, že na ní lze pěstovat ovoce či zeleninu.

Mezi nevýhody se řadí potřeba kvalitně provedené hydroizolace, bez které by vlhkost mohla difundovat do stř̌ešního souvrství a dále do interiéru; navíc je nutné volit hydroizolaci s odolností proti prorůstání kořínků. Nosná konstrukce musí být dostatečně pevná, aby unesla přidanou hmotnost vegetační střechy, a jistá omezení se projevují i v nutnosti aplikace pouze do povoleného sklonu; bez přidaných stabilizačních konstrukcí ji lze instalovat pouze na ploché nebo mírně skloněné střechy. Z hlediska finančních nákladů se pak musí brát v úvahu zvýšené náklady na instalaci zelené střechy, které mohou dosahovat až dvojnásobné úrovně vůči nákladům na instalaci klasické střechy. Vegetační střechy jsou náročnější na údržbu, protože je třeba alespoň jednou do roka odstranit nežádoucí rostliny [2]. 


\section{SKLADBA VEGETAČNÍ STŘECHY}

Zelené střechy se zpravidla dělí na dva druhy, extenzivní a intenzivní. Takto to uvádí i norma ČSN 731901. V současné době je zejména ve větších městech trend pomocí vegetačních střech zlepšovat životní prostředí. Nejčastěji jsou navrhovány $\mathrm{v}$ administrativních, obchodních a zábavních centrech [3].

Souvrství vegetační střechy se dá v zásadě rozdělit na dvě základní části: vegetační část a nosný plášt'. Tento článek se zabývá pouze částí vegetační neboli také pěstební. Ta se dělí na níže uvedené vrstvy:

- vegetační vrstva - vhodně zvolené rostliny,

- mulčovací vrstva - mulčovací kůra, štěpka, kamenná drt' aj.,

- $\quad$ substrát zeminy,

- hydroakumulační vrstva (vrstva zadržující vodu) - např́iklad rašelina, hydrofilní desky, role z minerálních vláken nebo nehydrofobizovaná křemičitá vata,

- filtrační/separační vrstva - skelné rohože, sklotextilie, geotextilie, kamenivo či kamenná drt' aj.,

- drenážní vrstva - nopové fólie, kamenná drt', strukturované rohože z plastu nebo pryže aj.

Výše uvedené pořadí vrstev má pouze orientační charakter; některé vrstvy mohou plnit více funkcí a jiné mohou být úplně vynechány, pořadí se může lišit. Stále ještě převládá názor, že na hydroizolaci musí být položena vrstva odolná vůči prorůstání kořenů rostlin. Ta se dnes však používá zcela výjimečně (v takovém případě se většinou jedná o speciální polyethylenovou fólii), a to při rekonstrukcích, kde se pokládá na původní vodotěsnou izolaci z asfaltových pásů. Jako hydroizolace zelených střech se dnes zpravidla používají asfaltové pásy, které jsou modifikované aditivy zabraňujícími prorůstání, nebo hydroizolační membrány, přičemž oba typy hydroizolace jsou již proti prorůstání kořenů rostlin testované [3].

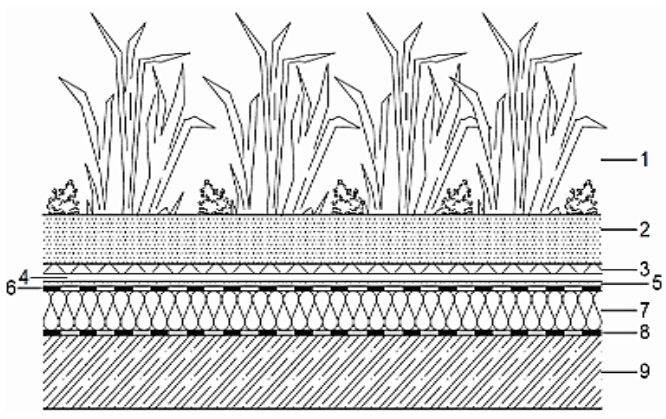

Obr.1 Obecná skladba střešního pláště zelené střechy [3]. Popis vrstev: 1. vegetace, 2. substrát, 3. filltrační vrstva (geotextilie, kamenivo...), 4. drenážní a hydroakumulační vrstva (nopová fólie), 5. ochranná vrstva hydroizolace (textilie), 6. hydroizolace (splňující FLL test proti prorůstání), 7. tepelná izolace, 8. parozábrana, 9. nosná stř̌ešní konstrukce.

\section{Extenzivní zelené stř̌echy}

U extenzivních zelených střech se pro plošné ozelenění využívají kombinace rostlin, které se vyskytují i na přirozených stanovištích. Vegetace se udržuje samovolně, a i na malé vrstvě substrátu vytváří trvalý a zapojený rostlinný porost. Výhodou extenzivního ozelenění je, že ho lze zakládat i na střechách s poměrně nízkou únosností. Potřebná tloušt'ka substrátu je velmi malá (50 až $150 \mathrm{~mm}$ ), takže dochází k minimálnímu přitižení střešní nosné konstrukci. Na druhou stranu výběr rostlin pro extenzivní zazelenění je poměrně náročný. Musí to být rostliny, které se př́liš nerozrostou a které nepotřebují žádnou péči, protože vodou a živinami jsou zásobovány pouze přirozenými procesy. Doporučuje se například pažitka, ostřice nízká, kostřava nebo rozchodníky [4].

\section{Intenzivní zelené střechy}

Intenzivní zelení střechy se vyznačují tím, že vrstva substrátu je vyšší (pohybuje se v rozmezí 300 až 1000 mm), a proto je třeba únosnost střechy větší než $3 \mathrm{kN} \cdot \mathrm{m}^{-2}$. Systém dokáže dobře zadržovat dešt'ovou vodu, což má význam při zavlažování v suchém období. I tak je ale nutné počítat s umělým zásobováním vodou a živinami. Díky vyšší vrstvě substrátu se zde mohou pěstovat i náročnější rostliny jako růže, nízké křovinaté rostliny a při odpovídajícím zvýšení vegetační vrstvy i střední a vyšší keře. Výška porostu může dosahovat až $250 \mathrm{~cm}$. Intenzivní 
zelená střecha většinou slouží i jako odpočinková zóna a předpokládá se tam pracovní nebo rekreační pohyb osob. Hodí se tak jako rozšíření užitného prostoru [4].

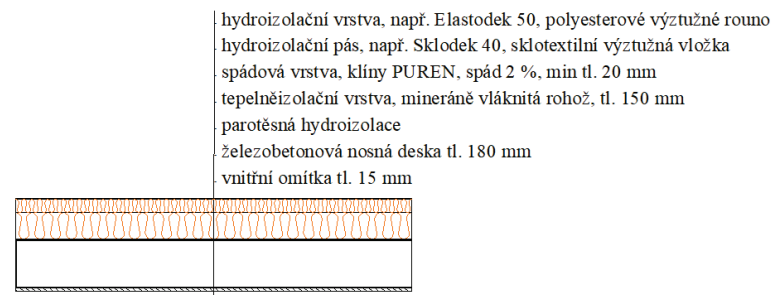

Obr. 2 Skladebné uspořádání vrstev střešního pláště u klasické ploché střechy.

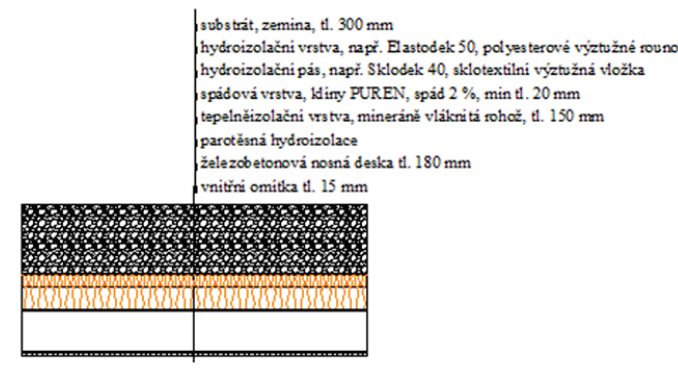

Obr. 3 Skladebné uspořádání vrstev střešního pláště u intenzivní vegetační stř̌echy.

\section{POPIS VYBRANÉ MODELOVANÉ BUDOVY}

Řešená stavba je dřevostavba rodinného domu o jednom nadzemním podlaží bez podsklepení. Obvodové konstrukce jsou zatepleny externím zateplovacím systémem s izolantem z minerální vlny o tloušt'ce $150 \mathrm{~mm}$. V př́ípadě klasické ploché střechy je tepelná izolace střešní konstrukce z minerální vlny o tloušt'ce $150 \mathrm{~mm}$ a v př́ípadě intenzivní vegetační střechy je z EPS o stejné tloušt'ce. Přesnější skladby stř̌ešních konstrukcí jsou uvedeny výše.

Objekt je obdélníkového tvaru s půdorysnými rozměry $11 \times 14$ m. Světlá výška místností je 2,6 m. Celkový obestavěný prostor činí přibližně $660 \mathrm{~m}^{3}$.
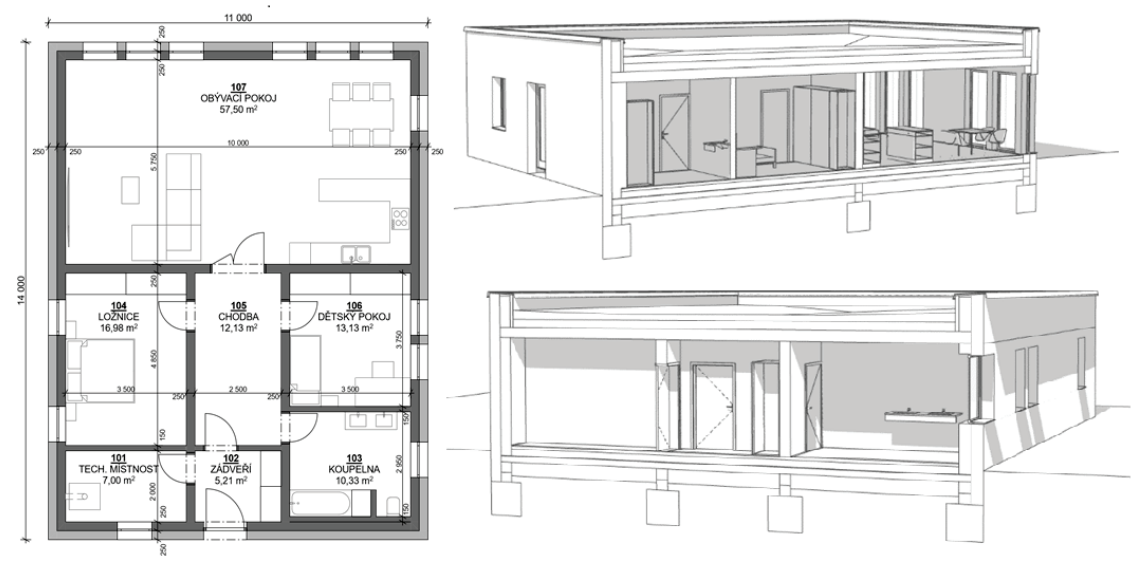

Obr. 4 Tvarové řešení objektu. 


\section{NESTACIONÁRNÍ VÝPOČET PRŮBĚHU TEPLOT VE STĚNÁCH}

Průběh teplot lze stanovit pomocí softwaru Stabil, jak popsal S. Št'astník [5]. Výsledky výpočtů rozdělení teplotního pole se od skutečného stavu za reálných podmínek moc neliší, jelikož okrajové podmínky, které vstupují do výpočtu, jsou stejně proměnné jako ty ve skutečnosti. Za pomocí softwaru Stabil byl naprogramován výpočet průběhu teplot $\mathrm{s}$ časově proměnnými exteriérovými okrajovými podmínkami. V simulačním programu jsou zohledněny podmínky šíření tepla v celém stavebním objektu podle principu tepelného systému a je také zohledněn pohyb slunce po obloze. Jak je zmíněno výše, hodnoty exteriérových teplot byly poskytnuty meteorologickou stanicí z letiště Brno Tuřany. Data odpovídají jednomu referenčnímu klimatickému roku.

Pro potřeby této práce byla namodelována budova o jednom nadzemním podlaží a sedmi místnostech. V prvním výpočtu se uvažovala skladba ploché střechy s klasickým pořadím vrstev a do druhého výpočtu byla započítána i zemina, a to o mocnosti vrstvy $100 \mathrm{~mm}$ [5].

Software Stabil dále operuje s geometrií objektu tedy i se slunečním ozářením objektu, materiálovými vlastnostmi skladeb a teplotami vzduchu v okolí objektu.

\section{Vztahy pro výpočet vazebného tepelného toku}

Vazebným prvkem mezi jednotlivými místnostmi je tepelný tok, tedy vazebný tepelný tok. Př́i šírení tepla mezi místnostmi v budovu jej lze rozšířit na tyto složky:

1) přestup tepla mezi okolním vzduchem a povrchem stěny:

$$
\dot{q}^{i j}(\tau)=h_{s}^{i j} \cdot S^{i j} \cdot\left(t_{a}^{i}(\tau)-t_{S}^{i j}(0, \tau)\right)
$$

2) šíření tepla stěnou. Jedná se o Fourierovu rovnici vedení tepla pro jednorozměrný př́ípad:

Počáteční okrajové podmínky:

$$
\frac{\partial t}{\partial \tau}=a \cdot \frac{\partial^{2} t}{\partial x^{2}} \mid \tau \geq 0 \wedge 0 \leq x \leq d
$$

- počáteční teplota $(x, 0)=t_{0}=$ const

- okrajové $t(0, \tau)=q_{s}^{i}(\tau)$, resp. $t(d, \tau)=q_{s}^{j}(\tau)$

3) šíření mezi okolním vzduchem a povrchem stěny:

4) toky ventilačního vzduchu a spárové netěsnosti v místnosti:

$$
\dot{q}^{j e}(\tau)=h_{s}^{e j} \cdot s^{j e} \cdot\left(t_{s}^{j e}(d, \tau)-t_{e}(\tau)\right)
$$

$$
\dot{q}_{v}^{i}(\tau)=V^{i} \cdot c_{a i r} \cdot\left(t_{a}^{i}(\tau)-t_{e}(\tau)\right)
$$

5) tepelná radiace mezi vnitřními povrchy v místnosti:

$$
\dot{q}_{r}^{i}(\tau)=S^{i} \cdot c_{b} \cdot A \cdot\left[\left(\frac{T_{s}^{i j}(\tau)}{100}\right)^{4}-\left(\frac{T_{s}^{i k}(\tau)}{100}\right)^{4}\right]
$$

\section{Průběh teplot vzduchu v místnostech se střechou s klasickým pořadím vrstev}

Maximální vypočtená teplota vzduchu v místnosti byla $30,1^{\circ} \mathrm{C}$ a minimální teplota byla vypočtena na $5,1^{\circ} \mathrm{C}$. Podrobnější průběh teplot je znázorněn níže v Obr. 6. Přičemž je jako teplota 1 označena vypočtená teplota v místnosti 101, teplota 2 označena vypočtená teplota v místnosti 102 atd. 

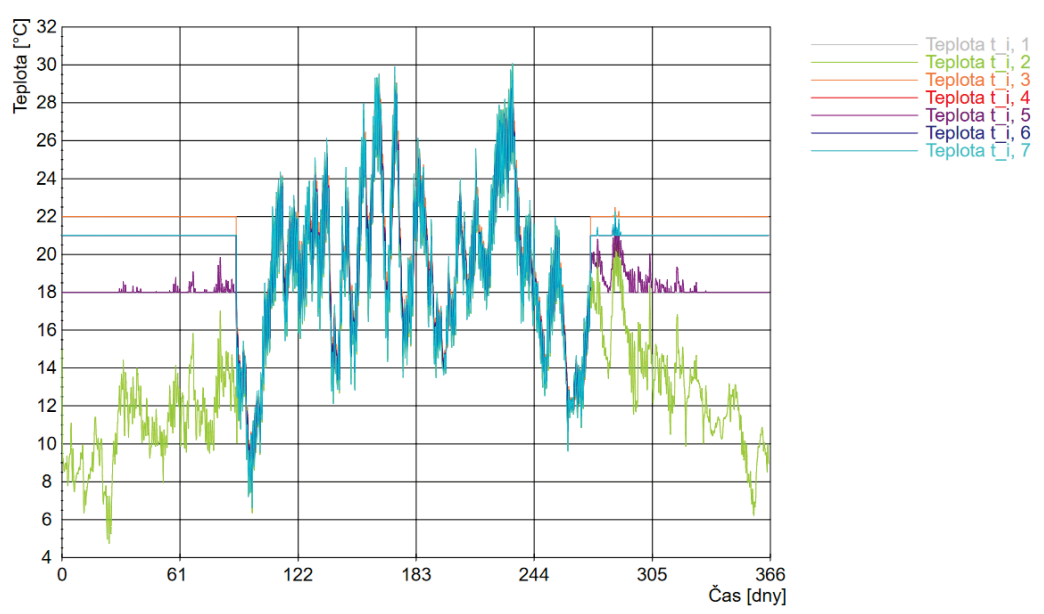

Obr. 5 Průběh teplot v klasické ploché stř̌eše.

\section{Průběh teplot vzduchu v místnostech s intenzivní vegetační stř̌echou}

Maximální vypočtená teplota byla $28,4{ }^{\circ} \mathrm{C}$ a minimální teplota byla vypočtena na $5,1{ }^{\circ} \mathrm{C}$. Podrobnější průběh teplot je znázorněn níže v Obr. 6.
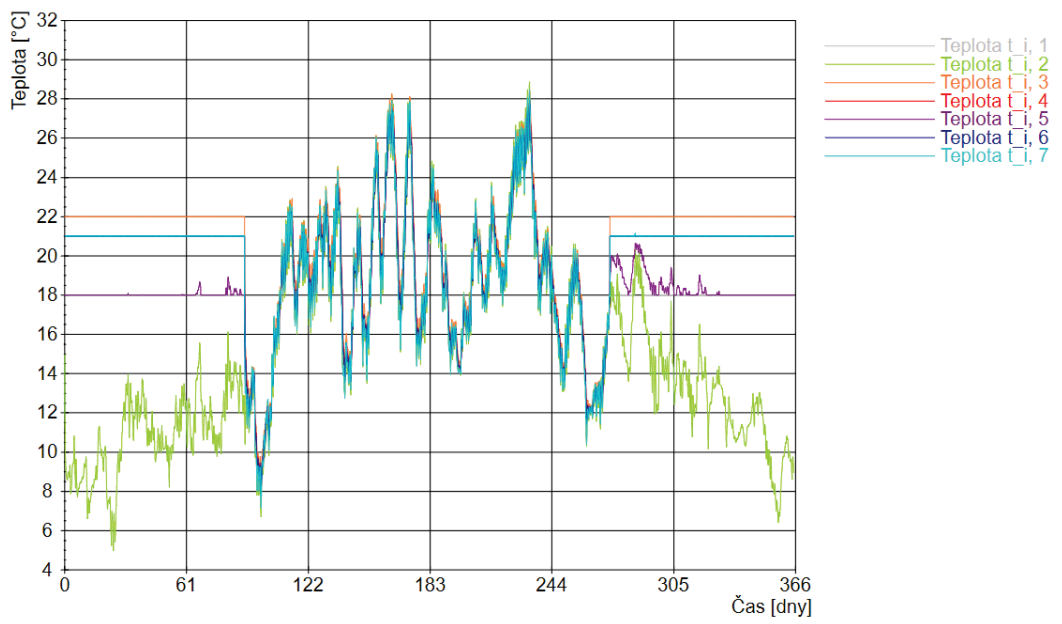

Obr. 6 Průběh teplot v ploché vegetační střeše se 100 mm zeminy.

\section{ZÁVĚR}

Cílem tohoto př́íspěvku je poukázat na pozitivní vliv konstrukce vegetační střechy na teplotní průběh $\mathrm{v}$ místnostech, čímž se přispívá $\mathrm{k}$ zajištění potřebné tepelné pohody. K této skutečnosti dochází díky značné tepelné jímavosti zeminy a zde se ji podařilo výpočtově prokázat. Vypočtené hodnoty se ovšem mohou od reality trochu lišit, nebot' teplotu na povrchu konstrukce ovlivní i volba vysazené zeleně, způsob zavlažování, míra zhutnění zeminy aj. V reálné situaci pohltí velké množství tepla i listy zeleně, to však ve výpočtu nešlo zohlednit.

Lze ale očekávat, že skutečné teploty by byly výrazně př́íznivější oproti výpočtové simulaci. 
nestacionárně s využitím denního chodu reálných okrajových venkovních teplot. Použitím stacionárních nebo kvazistacionárních okrajových venkovních teplot, které se obvykle využívají pro stanovení energetické náročnosti budov, nelze uvedený účinek zachytit.

Náročný simulační výpočet, v němž se uplatní materiálové vlastnosti prvků skladby konstrukce (zejména součinitel tepelné vodivosti, objemová hmotnost a tepelná kapacita), však poskytuje reálnější obraz o teplotních pochodech probíhajících v celém stavebního objektu jakožto tepelném systému.

Zatímco u střechy s klasickým pořadím vrstev byla maximální teplota v letním období vypočtena jako hodnota $30,1{ }^{\circ} \mathrm{C}$, u střechy vegetační to je (za předpokladu stejného typu budovy, zachování geometrie atd.) $28,4{ }^{\circ} \mathrm{C}$. Tyto hodnoty teplot byly vypočteny pro místnost č. 107, obývací pokoj. Došlo zde tedy ke snížení teploty o 1,7 K. Minimální teplota byla vypočtena v obou případech stejná, a to $5,1^{\circ} \mathrm{C}$ pro místnost č. 102 , zádveří.

Jak již bylo zmíněno, vliv vegetační střechy bude $\mathrm{v}$ reálných podmínkách příznivější díky působení vegetace na povrchu vegetační střechy. Pro své mnohé klady mají zelené střechy v zemích s drsnějšími klimatickými podmínkami už dlouhou tradici [6].

Pro realizaci vegetační střechy je třeba stavební projekt a statický posudek objektu. Při malém sklonu střechy, tedy sklonu pod $5^{\circ}$, se doporučuje instalovat navíc systém vnitřního odvodnění střechy. Při sklonu vyšším než $30^{\circ}$ se vegetační střecha nedoporučuje.

Vegetační střecha má př́znivé tepelně izolační vlastnosti, umožňuje pěstování rostlin na ploše, kde to jinak není možné, a přitom zlepšuje mikroklima místností. Zelená stř̌echa tedy za letních veder udržuje př́ijemnější klima v objektu, chrání dům před klimatickými vlivy, tepelnými úniky a přehříváním a rozšiřuje plochu zeleně na parcele. Voda, která se odpařuje, navíc ochlazuje stř̌ešní konstrukci, což v interiéru vytváří spolu s pomalejším prostupem tepla významně chladnější prostředí. Nejde tedy jen o zamezení přehřívání.

Z uvedených vypočtených hodnot můžeme vyvodit, že vliv vegetační střechy na tepelnou stabilitu se dá očekávat pouze $\mathrm{v}$ letních měsících, zatímco $\mathrm{v}$ zimních měsících energie potrebná na vytápění pro udržení minimální požadované teploty není významně ovlivněna.

\section{Poděkování}

Tento výzkum byl projektem specifického výzkumu Vysokého učení technického v Brně NO. FAST-J-21-7471.

\section{Použité zdroje}

[1] ČERMÁKOVÁ, Barbora a Radka MUŽÍKOVÁ. Ozeleněné střechy. Praha: Grada, 2009. Stavitel. ISBN 978-80-247-1802-6.

[2] Plusy a mínusy zelené střechy pokryté živou vegetací. Bydlímeútulně.cz [online]. JJV Group, 25. 2. 2020 [cit. 2021-06-10]. Dostupné z: https://bydlimeutulne.cz/plusy-a-minusy-zelene-strechy-pokryte-zivouvegetaci/.

[3] Teorie zelených střech. Gazda: projekční a inženýrská činnost [online]. 3. 9. 2011 [cit. 2020-09-11]. Dostupné z: www:http:/gazda.webpark.cz/gr/theory.htm.

[4] Extenzivní a intenzivní ozelenění střech. Liapor [online]. Vintířov: Lias Vintírov [cit. 2021-06-10]. Dostupné z: https://www.liapor.cz/produkty/kamenivo/liadrain/aplikace/ozeleneni-strech.

[5] PRŮŠA, David, Stanislav ŠŤASTNÍK, Karel ŠUHAJDA a Tomáš ŽAJDLÍK. Numerické řešení vlivu vegetační vrstvy na teplotu v jednotlivých vrstvách vegetační ploché střechy. TZB-info [online]. Topinfo, 2021, 29. 3. 2021 [cit. 2021-06-10]. ISSN 1801-4399. Dostupné z: https://stavba.tzbinfo.cz/prostup-tepla-stavebni-konstrukci/22048-numericke-reseni-vlivu-vegetacni-vrstvy-na-teplotuv-jednotlivych-vrstvach-vegetacni-ploche-strechy.

[6] MINKE, Gernot. Dächer begrünen: Planung, Ausführung, Praxistipps. Staufen bei Freiburg: Ökobuch, 2016. ISBN 978-3-936896-89-3. 